\title{
Roles of the Crisis Management Initiative (CMI) in Aceh's Reconciliation to Strengthen Indonesia's National Integration After Tsunami in 2005
}

\author{
Mujiburrahman \\ Doctoral Program of History, Faculty of Humanities, Diponegoro University \\ Faculty of Teacher Training and Education, Universitas Serambi Mekkah, Aceh \\ Indonesia
}

\begin{abstract}
Crisis Management Initiative (CMI) is a National Government Organization that focuses on advocacy for sustainable security and conflict resolution. This organization was founded in 2000 by Martti Ahtisaari. Ge was the former president of Finland in 1994-2000. CMI was asked to facilitate negotiation between the Indonesian government and GAM (Free Aceh Movement), through personal contact between Farid Husain and Juha Christensen. Aceh conflict was a disintegrationoriented-conflict, so it was potential to threaten Indonesia's sovereignty.

This research used the historical method with heuristic, criticism or verification, interpretation, and historiography stages. The primary sources of data on this research were information in the media, both printed and electronic. Besides, this research also examined or reviewed

Received:

December 8, 2018

Revised:

December 29, 2018

\section{Accepted:}

January 23, 2019

\section{Corresponding author:}

mujiburrahman@serambimekkah.ac.id the literary references that were related and relevant to the research topic. The study was to reveal how the background of CMI's involvement in Aceh peace in 2005, and how the strategic roles of CMI in resolving conflicts until the realization of Aceh peace in 2005 for Aceh remained a part of the Republic of Indonesia (NKRI).

The role of CMI as a reputable international institution and getting the trust of both parties, was capable of providing intervention to the conflicting parties so that its role became very strategic in mediating the conflict. The success of CMI was seen from the negotiation held in Helsinki Finland, resulting in the execution of the Memorandum of Understanding (MoU) on August 15, 2005, as a peace agreement. After the signing of the Helsinki MoU, armed conflict stopped, and the social lives were back to normal, and the development process could resume usually.
\end{abstract}

Keywords: CMI; Reconciliation; Aceh; National Integration.

\section{Introduction}

The conflict between Free Aceh Movement (GAM) and the Government of the Republic of Indonesia (RI) was an unresolved conflict (1976-2005), which drew attention of all parties. Moreover, after Aceh was hit by an earthquake and tsunami, this disaster increased the international attention to Aceh. After the tsunami demolished Aceh, all eyes were on Aceh. Even before the tsunami hit, Aceh is already an international concern. Yet, it was not so full, the international attention to Aceh before the tsunami focused on the issue of armed conflict, in which fatalities happened almost every day. One of the international concerns HDC (Henry Dunant Center) once sought peace between GAM and NKRI. But after the tsunami hit Aceh, the intensity of international attention to Aceh was much higher, both on the disaster and on escalating GAM and NKRI conflicts.

The first peace effort mediated by HDC between GAM and NKRI was failed. The dialogue began at the beginning of May 12, 2000 reaching to an agreement which was called as an agreement for humanitarian pause. The fundamental to be achieved was to open humanitarian access to the critical areas caused by conflicts and its impact in Aceh. It was also an agreement to start establishing trust between GAM and the TNI. The humanitarian pause finally ended on January 15, 2001.

On Sunday morning, December 26, 2004, an 8.9 Richter scale earthquake shook the Land of Rencong with the epicenter located on the west coast of Sumatra Indonesia at longitude of $3.316^{\circ} \mathrm{N} 95.854^{\circ} \mathrm{E}$, approximately $160 \mathrm{~km}$ on western of Aceh by 10 kilometers deep. Shortly after the earthquake, tsunami swept 
the coast of Aceh. This tremendous wave hit the coast of Aceh for 800 kilometers. Because of this natural force, 200,000 people died and 500,000 people became refugees (Madya, 2009: 71). Many buildings were totally demolished by the tsunami. Banda Aceh, Aceh Besar, Aceh Jaya, and West Aceh were greatly damaged. The tsunami gave a great hope to GAM and the Republic of Indonesian (NKRI) negotiations, under the pretext of pain suffered by Aceh people. The tsunami became a momentum to knock the hearts of both parties to stop hostilities.

Crisis Management Initiative (CMI) was founded in 2000 by the former Finnish President who served in 1994-2000, Martti Oiva Kalevi Ahtisaari. CMI is a non-governmental organization (NGO) engaged in advocacy for sustainable security and many other segments of conflict resolutions. It is headquartered in Helsinki, Finland. It was asked to mediate negotiations between GAM and the government of the Republic of Indonesia through personal communication between Farid Husain, the Deputy Minister of Social Welfare with a Finnish businessman named Juha Christensen.

CMI focuses on Conflict Prevention and Crisis Response, bringing a new hope to end the bloody conflict that causing many victims. In peacekeeping phase, CMI slowly began to decline the violence conflict, and turned it into a non-violent dialogue. The barometer of CMI's success in bringing peace between GAM and NKRI was the signing of the Helsinki MoU on August 15, 2005 as a peace agreement. The sweet fruit of the Aceh peace is certainly inseparable from CMI. The existence of CMI in encouraging peace in Aceh is influential. CMI facilitated the conflicting parties to sit on a table and have a dialogue to find a common ground so that Aceh peace can be realized. Starting from the explanation above, it is interesting to see how CMI roles in Aceh peace.

\section{Method}

This research used historical method, a set of rules systematically used to search or find historical sources. Afterward, critique was performed on the sources and made interpretations to present the results of the research in written or historiographic form. Louis Gottschalk explained historical method as a process of testing and analyzing historical events to find authentic and reliable data, and attempts to synthesize such data into a reliable historical story (Abdurrahman, 2007: 54). In a brief, these steps in consequence are often called heuristic, criticism or verification, interpretation and historiography. Actually there is one important activity namely the selection of topic before those four steps, which is added by Kuntowijoyo to form the five stages of historical research (Kuntowijoyo, 1995: 89). The source used in this study at the heuristic stage was the media, both printed and electronic media. The use of these sources was quite relevant in fulfilling the data, because the Aceh peace process received high attention from various media. Also, books that are relevant to the research topic, as well as supporting journals as a previous study on the same topic were used in this research.

\section{Initial Pilot of RI-GAM Peace}

During the New Order, the Aceh conflict has never been touched by settlement through negotiation, except only through military approach which claimed many casualties. During Abdurrahman Wahid reign, GAM and NKRI conflicts began engaging the third party which was Henry Dunant Center (HDC), even though the resolution of the conflict failed. SBY-JK gave more chances to solve Aceh conflict through dialogue. Negotiation indeed must involve the conflicting parties. Nevertheless, the conflicting parties were the main actors that had to be involved and played an active role in the negotiation process to achieve a solution. Yet, the tendency for conflict usually involved outsiders as well. It was due to four issues (Miall, 2000: 48); (1), the origin of the conflict was greatly affected by external factors; (2) the existing global interdependencies resulted in the need for third parties to intervene as prevention so that conflicts did not extend to their countries; (3) the price of conflict in the form of humanitarian tragedy made the outside party to be legitimate to involve or intervene; (4) there was a common understanding that almost all conflict studies showed that protracted conflict could only be resolved by involving outsiders.

Referring to the assumptions above, it was impossible to rely on the involved countries too much to deal with their own issues. It was undebatable that the State faced difficulties to get trust from the opposition parties. In the context of internal conflict, the state was not a trusted institution because it was usually the instrument of the dominant group. The state could not be a neutral arbitrator (third party), but became a part of the conflicting party (second party). The involvement of third parties was needed to mediate the conflict to prevent the threat to global peace as well as the ongoing violence. Third party interventions in international conflict had a long history and reached a broad spectrum of various scientific disciplines and was evolving over time. 
Simply put, third parties were individuals or collectives who were outside the conflict between two or more parties who tred to help them solving the problem various consensus (Rubin and Jeffrey Z., 2004: 374).

Furthermore, the intervene of third party in a conflict would change the destructive nature of a conflict and reduced the escalation of conflict since the presence of third parties could divert the attention of the perpetrators of the conflict to resolve the conflict. Third parties had important strength or a very strong role in realizing peace from the conflicting parties. However, third parties were not panacea for conflict resolution. It might be a good medicine, but it was possible to give side effects. The main medicine for recovery was indeed from within the body itself. The third party was a driving force to engage into a more effective conflict resolution (Rubin and Jeffrey Z., 2004: 374). It could be interpreted that the desire to create peacefulness from the conflicting parties themselves is very influential, even though the third party is also important. It is because the third party had a neutral position for the two conflicting parties to intervene the conflict. There were several conditions to meet to have a third-party intervention ran as expected and effective. Willingness to negotiate or be involved in problem solving activities had to exist. Without this willingness, the intervention would never happen even if there was a judge who ordered it. Second, a forum had to be agreed upon by all parties. Last but not least was the credibility of the intervention party (Zulkarnaen, 2005: 3). The explanation above showed that, the role of third party was influential to reach an agreement between the conflicting parties.

Farid Husain, one of the people involved in Aceh peace, served as a lobbyist. Farid Husain's involvement in Aceh peace started around August 2003 (Husain, 2007: 3-4). He was ordered by Jusuf Kalla (JK) who was served as the Coordinating Minister for People's Welfare at that time, to explore the opportunities to seek peace in Aceh that was more dignified, comprehensive and able to break the chain of the prolonged conflict which claimed many lives. The light at the tunnel was finally seen on January 2005 when he welcomed Juha Christensen, an anthropologist who held a research at the Hasanuddin University, Makassar. He also worked as a lecturer at the medical faculty in Hasanuddin University. In short, Christensen was entrusted to become an 'intermediary' of Farid's lobby to the GAM leaders in Sweden and also to the Swedish government to the very important phase of meeting Martti Ahtisaari.

The process of CMI's involvement in Aceh peace was very different from its earlier HDC. HDC was involved in GAM and NKRI negotiations because the HDC visited President Abdurrahman Wahid offered a good service to be a mediator for negotiations between NKRI and GAM. Meanwhile, the involvement of the CMI who was led by Martti Ahtisaari was based on government request. In this case, Farid Husein through Juha Christensen (from the Interpeace Organization) requested help from Martti Ahtisaari along with her institution, CMI, to become the negotiator for the peace. Juha Christensen then tried to convince Ahtisaari and GAM party in Sweden, while Farid Husein, on JK and SBY's guarantee, was assigned to convince the Indonesian side (Hadiwinata, 2010: 88). In the first phase, it showed that CMI has a high bargaining position in providing political intervention to the parties. Therefore, the role of CMI was very strategic for both parties to reach an agreement.

Choosing CMI was based on very rational considerations. First, Martti Ahtisaari was a former president and had strong political influence both in European Union and the United Nations. Ahtisaari had political access and was able to get the support needed from the countries and/or international organizations. Second, he also had broad experience in facilitating peaceful solution to conflicts, such as in Kosovo and in Africa. Leadership, experience and reputation of CMI were good in terms of conflict resolution (Hadiwinata, 2010: 92). One of the most obvious event was when he represented the European Union (EU) in 1990 for the negotiation with the President of Serbia, Slobodan Milosevic, which resulted outstandingly marked with the end of Kosovo conflict (Husain, 2007: 55).

The meeting with Martti Ahthisaari offered a glimmer of hope, for he was willing to be a facilitator and negotiator for RI-GAM negotiations. Farid Husain's lobbying and follow up communication continued. Tsunami on December 2004 devastated the socio-economic, educational and health of Acehnese people, creating a condition that strongly urged RI-GAM negotiations to find a peace solution in Aceh and then deal with tsunami victims quickly and accurately (Amiruddin, 2007). The Aceh tsunami on December 26, 2004 was an international disaster, this tremendous disaster opened up huge opportunities for the parties to end the conflict based on a shared sorrow. Coupled with the disaster, it made the international eye fixed on Aceh. It became an energy to reach a peace agreement.

The first negotiation began on January 27, 2005. Indonesia sent five representatives, namely Minister of Law and Human Rights Hamid Awaluddin as head of the delegation, Minister of Communication and Information Sofyan Djalil, Farid Husain, Deputy Coordinating Minister for Politics and Security, Maj. Gen. (Retired) Usman Basyah and Director of Human Rights, Humanity, and Social Culture I Gusti Agung Wesaka Puja. Meanwhile, GAM delegation consisted of three GAM Sweden namely Malik Mahmud as Chair of the Delegation, Zaini Abdullah, and Bachtiar Abdullah, and GAM Australia Nurdin Abdul Rachman and GAM 
Singapore Nur Juli. They were the delegations who carried out the negotiation to make an agreement on achieving Aceh peace.

\section{CMI's Contribution to Aceh Peace 2005}

To resolve a conflict which occurred for a long time, it was certainly not as easy as turning the palm for establishing a smooth negotiation process. Often, a conflict resolution with category as a chronic one was very necessary for a neutral party acting as a mediator to facilitate the negotiation process as conflict resolution. So, Aceh peace agreement had to involve the third party. It was because the negotiation process required a trusted party who was neutral and chosen by the conflicting parties.

CMI as an international institution finally acted as the third party in GAM and NKRI negotiations where Ahtisaari acted as a mediator in the dialogue process to seek peace between GAM and NKRI as an institution focusing on advocacy for security and other aspects of conflict resolution. In Aceh peace, CMI played a very strategic role. It was because CMI acted as a negotiator between Indonesian government and GAM. Ahtisaari was the mediator in the dialogue process and the representation of CMI at the same time.

The persistence of CMI in pursuing Aceh peace had produced results that were highly expected by the people of Aceh. The bloody conflict that had occurred for about 29 years could finally be ended in a dignified manner. This success could not be separated from CMI role as the third party that played a very strategic role in realizing peace in Aceh. The success of resolving the Aceh conflict, the minister of Finland, nominated Martti Ahtisaaari as the Nobel Peace Prize recipient. October 10, 2008 became a historic day for Ahtisaari, where on that day Martti Ahtisaari won the Nobel Peace Prize. Ahtisaari's Nobel Prize was an indicator that his presence as a mediator in Aceh peace was very instrumental.

\section{Realization of Aceh's Reconciliation}

As explained above, in 2004 the biggest natural disaster occurred in Aceh, which was the earthquake and tsunami. Earthquake and tsunami in Aceh devastated almost all life in Aceh and resulted in the death of more than one hundred thousand people, which caused the attention of the conflicting parties to split between continuing conflict with the central government or rebuilding life in post-tsunami Aceh. It must be admitted that, there every cloud had silver lining as after the tsunami hit Aceh, the conflicting parties were willing to reconcile for the sake of stability in Aceh to be restored. Departing from one of these reasons, efforts to stop hostilities had to be immediately taken to build Aceh that had been devastated by the tsunami. It was impossible to achieve peacefulness in an armed conflict. For the first time in a long history of conflict in Aceh, the Government and GAM with mediation by an independent institution (CMI), succeeded in establishing an agreement signed by the Memorandum of Understanding (MoU) in Helsinki, Finland, 15 August 2005 (Kawilarang, 2008: 11). As outlined in Vayrynen's theory, conflict resolution could be done if one was willing to be the mediator. In the case of Aceh, Martti Ahtisaari's willingness to be a mediator at the Helsinki negotiation changed the structure of the Aceh conflict which was only involving the Indonesian Government and GAM to be mediated by the third party, Ahtisaari. In terms of the structure of this relationship, Ahtisaari's role was very important because he could put pressure on both the government and GAM, for example asking GAM to stop talking about independence anymore. As a compensation, he asked the government to allow GAM to form a local party. It was his pressure on both parties that finally led the Government and GAM to agree to stop the conflict (Djumala, 2013: 106).

Moreover, he was able to break the communication deadlock and able to encourage GAM and NKRI to communicate flexibly by reducing the level of demands of each party. The Indonesian government had to provide an offer that was higher than the previous autonomy and GAM had to decrease its demands of independence (Zainal, 2016: 94). Not only he was able to limit the communication on topics that would put the forum into a deadlock, he also set a time limit for the dialogue. The negotiation could run within the context of autonomy framework in a complete, intact, gradual discussion and had to be ended on July 2005 (Zainal, 2016: 95). He limited and forbade the independence topic during the dialogue process, so it resonated a profound effect on the dialogue which finally resulted in a peace agreement, often called the 2005 Helsinki MoU. It was what distinguished HDC and CMI in facilitating Aceh peace. According to Perez (2009) in Suadi Zainal, the failure of HDC was due to weak political leadership to push the negotiation towards peace agreement and the poor experience in holding negotiations. It did not involve massive international parties, as applied by CMI (Zainal, 2016: 93).

Achieving peace in a conflict such as the case of GAM and the Republic of Indonesia was very much determined by the mediator, Martti Ahtisaari. Although the establishment of Aceh peace was influenced by 
multi factors, the good faith of both parties was also a decisive point for attaining peace beside the natural factors that had destroyed Aceh. It also became a driving force for Aceh peace. According to Abbas, failure or success of a mediation was largely determined by the role played by the mediator. In this process the mediator became the catalyst that encouraged the realization of constructive discussions where the parties were actively involved in discussing the roots of their conflict to find solutions (Abbas, 2011: 77).

As explained above, that former Finnish President Martti Ahtisaari and CMI institution were selected and requested by the Indonesian government to mediate the peace negotiation. Choosing CMI as a meditator was also supported and approved by GAM. It was an important for the third party to be acknowledged and agreed by both parties (Hadiwinata, 2010: 10). With the background of CMI involvement in such an event, $\mathrm{CMI}$ in this case represented by Ahtisaari, could carry out its functions properly as suggested by Abbas.

Indonesia and GAM negotiation was held in Helsinki, Finland. The process of dialogue for amicably agreement ran in five rounds or stages. The first round took place on 27-29 January 2005. At this stage, it could be said that a framework for the dialogue was prepared (Iqbal, 2014: 157). The discussion included: the condition of Aceh which had just been destroyed by a tsunami, ceasefire and special autonomy framework (otsus) offered by the government. Autonomy here was a frame of reference for the following dialogue. At this stage, GAM wished that the talks about otsus should be put aside to avoid rigidity. While Martti Ahtisaari wanted the other way around. When the situation in this phase heated up, Ahtisaari made a statement "Don't try to bring the independence agenda here. You will only waste my time. If you still demand for independence, please take your leave and never come back." His statement was limit or the key for structuring the dialogue between the two parties. However, on the following day, the second round of the negotiation run quite good, such as on efforts to support the smooth distribution of international aid (Kingsbury, 2006: 23).

The second meeting was on February 21-23 2005. At this second meeting, the conversation began to point and touched the substantial issue. Both parties began talking about Special Autonomy, the concept of self-government, human rights and amnesty. The third meeting was held on 12-16 April 2005. At this stage, CMI was acting more as a meeting facilitator for both parties to lead the dialogue well and provide facilities such as legal experts for GAM. In this phase CMI played its role as an intermediary and played a bit part of lobbying role of the leader from each party. The fourth meeting took place on May 26-31, 2005; at this stage, the discussion was about the topic of political participation, security within the framework of Self Government, local party allowing GAM to carry out political activities who had the same rights as others, explanation of amnesty classification, integration facilities for victims of conflict. At this stage CMI also proposed the supervision from the European Union (EU). The next day, CMI facilitated the two parties to meet Peter Feith as the head of the mission appointed by EU. The fourth round negotiation was welcomed by the Vice President Jusuf Kalla, he stated that this stage had covered ninety percent of crucial issues, such as amnesty, economy and politics (Kingsbury, 2006: 100). The fifth meeting, or the last meeting, was held on July 12-17 as the summit meeting. Almost all issues had been agreed upon by the parties. However, this stage almost fell on a critical point when GAM raised the issue of local party. However, again CMI could bring the forum back to the MoU draft. Ahtisaari as a mediator showed his ability when the Indonesian Government provided lobbying in the context of local parties establishment which received rejection from some elements at that moment. In this deadlock situation, Farid Husain and Juha Christensen also increased their roles in lobbying both parties for an agreement. Finally, an agreement was made which read that the Indonesian government would facilitate the establishment of local party within a period of 1 year or 18 months at maximum after the Aceh peace was signed (Kingsbury, 2006: 154).

After the very crucial matter was approved, then other points of agreement were agreed upon by the delegation of both parties, GAM and NKRI. In the end, GAM and NKRI signed a memorandum of understanding $(\mathrm{MoU})$ on 15 August 2005 in Helsinki, Finland. The peace agreement was known as Helsinki MoU. The peace agreement also regulated an obligation for both parties to complete the Aceh Draft Law (RUU PA), in which Aceh Law accommodated the agreement treaty including to encourages the existence of monitoring institutions, namely Aceh Monitoring Mission (AMM). AMM was formed to disarmament and demobilize of Indonesian National Army (TNI) and GAM forces. AMM was led by Pieter Cornelis Feith, a Dutch. AMM had its headquarters and offices in eleven districts. Each office was occupied by 12 members of the monitoring team. In addition, AMM also had a number of deputies in charge of security issues, including the issue of disarmament, politics and monitoring of human rights issues. AMM authority as stated in the memorandum of understanding, was to monitor the reintegration of active GAM members into the community, monitor human rights enforcement, monitor the process of amendment of law, decide amnesty cases and investigate allegations of violations of the memorandum of understanding.

The presence of AMM in monitoring the course of peace agreement was very strategic. On this basis, the government awarded the chairman and several AMM members who were considered to be of great merit, 
such as AMM Chairman Pieter Feith who was awarded Main Class Merit Star Medal, former AMM Vice Chairman, Lieutenant General Nipat Thongklek from Thailand and AMM advisor Juha Cristensen from Finland were awarded First Class Merit Star Medal. The award was given by President Susilo Bambang Yudhoyono on August 18, 2006 at Istana Merdeka ("Presiden SBY Beri Penghargaan Bintang Utama Pada Martti Ahtisaari" https://www.merdeka.com/amp/khas/presiden-sby-beri-penghargaan-bintang-utama-padamartti-ahtisaari-6wgyiqv.html. Retrieved on October 10th, 2017). Based on the explanation above, it could be said that the tsunami on December 2004 brought the right momentum to build peace in Aceh. After the five round of negotiation process, on August 15, 2005, Indonesian government and GAM signed the Helsinki MoU. This peace agreement, in a nutshell, described a new climate in Aceh, especially in the aspect of governance and tried to overcome some social, political and economic issues which were in account for the causes of the conflict, and maintaining the national peace that was achieved by hard work. The Helsinki MoU accommodated several aspects of transitional justice, including: Amnesty for those imprisoned for participating in GAM activities, as well as affirming the obligation of the Indonesian government to implement ratified human rights treaties, specific timelines and indicators for demobilization, disarmament and decommissioning of GAM and Indonesian security forces in Aceh. This agreement also outlined the reintegration agenda for excombatants, political prisoners, and "civil society who had proven losses" (Madya, 2009: 79). This success showed that Ahtisaari, representative of CMI, played a significant role so that the negotiation process could be carried out effectively to finally make a peaceful agreement between GAM and the Republic of Indonesia.

\section{Conclusion}

The background of CMI involvement in Aceh peace in 2005 is because this institution has good international reputation and has won the trust of the Indonesian government and GAM as the parties of the conflict. CMI as the third party as a mediator was able to convince both parties (RI-GAM) to end the prolonged conflict that had given impacts on various aspects, such as economic, political and social. Finally, CMI was able to bring peace between the Indonesian government and GAM, establishing Helsinki MoU on August 15, 2005. The contribution achieved after CMI involvement in the resolution process between RI and GAM was the realization of peace in Aceh. After the execution of Helsinki MoU, the escalation of the number of violence decreased over time and the people could get their normal lives back and so, the development process in Aceh could run normally again without any more violence and armed contact. The end of the GAM and NKRI conflict was a success in maintaining the integration and integrity of NKRI.

\section{References}

Abbas, Syahrizal. Mediasi Dalam Perspektif Hukum Syariah, Hukum Adat dan Hukum Nasional. Jakarta: Kencana, 2011.

Amiruddin, M. Hasbi. Ulama Dayah pengawal Agama Masyarakat Aceh. Lhokseumawe: Yayasan Nadiya, 2007.

Djumala, Darmansyah. Soft Power untuk Aceh "Resolusi Konflik dan Poitik Desentralisasi". (Jakarta: Gramedia Pustaka Utama, 2013.

Dudung, Abdurrahman. Metodologi Penelitian Sejarah. Yogyakarta: Ar-Ruzz Media, 2007.

Hadiwinata, Bob Sugeng. Transformasi Gerakan Aceh Merdeka: dari Kotak Peluru ke Kotak Suara: sebuah Kisah Sukses Program Transformasi Kombatan di Aceh. Jakarta: Fredrich Ecert Stiftung, 2010.

Husain, Farid. To See the Unseen: Kisah di Balik Damai di Aceh. Jakarta: Health and Hospital Indonesia, 2007.

Iqbal, Muhammad, "Fenomena Kekerasan Politik di Aceh Pasca Perjanjian Helsinki", Jurnal Hubungan Internasional, Tahun Vol 7 (2) 2014.

Kawilarang, Harry. Aceh dari Sultan Iskandar Muda ke Helsinki. Banda Aceh: Bandar Publishing, 2008.

Kingsbury, Damien. Peace in Aceh: A Personal Account of the Helsinki Peace Process. Singapore: Ecolnox Publishing Asia, 2006.

Kuntowijoyo. Pengantar Ilmu Sejarah. Yogyakarta: Yayasan Benteng Budaya, 1995.

Madya, Muhammad Akbar. Merentas Jalan Damai Menuju Masa Depan. Jakarta: Lentera Demokrasi-Jyesta Publishing, 2009.

Miall, Hugh et.al. Resolusi Damai Konflik Kontemporer, translated by Tri Budhi Satrio. Jakarta: Raja Grafindo Persada, 2000.

Rubin, Dean G. Pruitt dan Jeffrey Z. Teori Konflik Sosial. Jakarta: Pustaka Pelajar, 2004. 
Zainal, Suadi, "Transformasi Konflik Aceh dan Relasi Sosial Politi di Era Desentralisasi”, Masyarakat: Jurnal Sosiologi, Vol. 21 (1) 2016.

Zulkarnaen, Iskandar. Peran Pihak Ketiga dalam Penyelesaian Konflik di Aceh. Banda Aceh: The Aceh Institute, 2005.

"Presiden SBY Beri Penghargaan Bintang Utama Pada Martti Ahtisaari" https://www.merdeka.com/amp/ khas/presiden-sby-beri-penghargaan-bintang-utama-pada-martti-ahtisaari-6wgyiqv.html. Retrieved on October 3th, 2017. 